\title{
Front Matter: Volume 7521
}

, "Front Matter: Volume 7521," Proc. SPIE 7521, International Conference on Micro- and Nano-Electronics 2009, 752101 (4 March 2010); doi:

$10.1117 / 12.855024$

EDIE Event: International Conference on Micro- and Nano-Electronics 2009, 2009, SPIE. Zvenigorod, Russian Federation 


\title{
PROCEEDINGS OF SPIE
}

\section{International Conference on Micro- and Nano-Electronics 2009}

\author{
Kamil A. Valiev \\ Alexander A. Orlikovsky \\ Editors
}

5-9 October 2009

Zvenigorod, Russian Federation

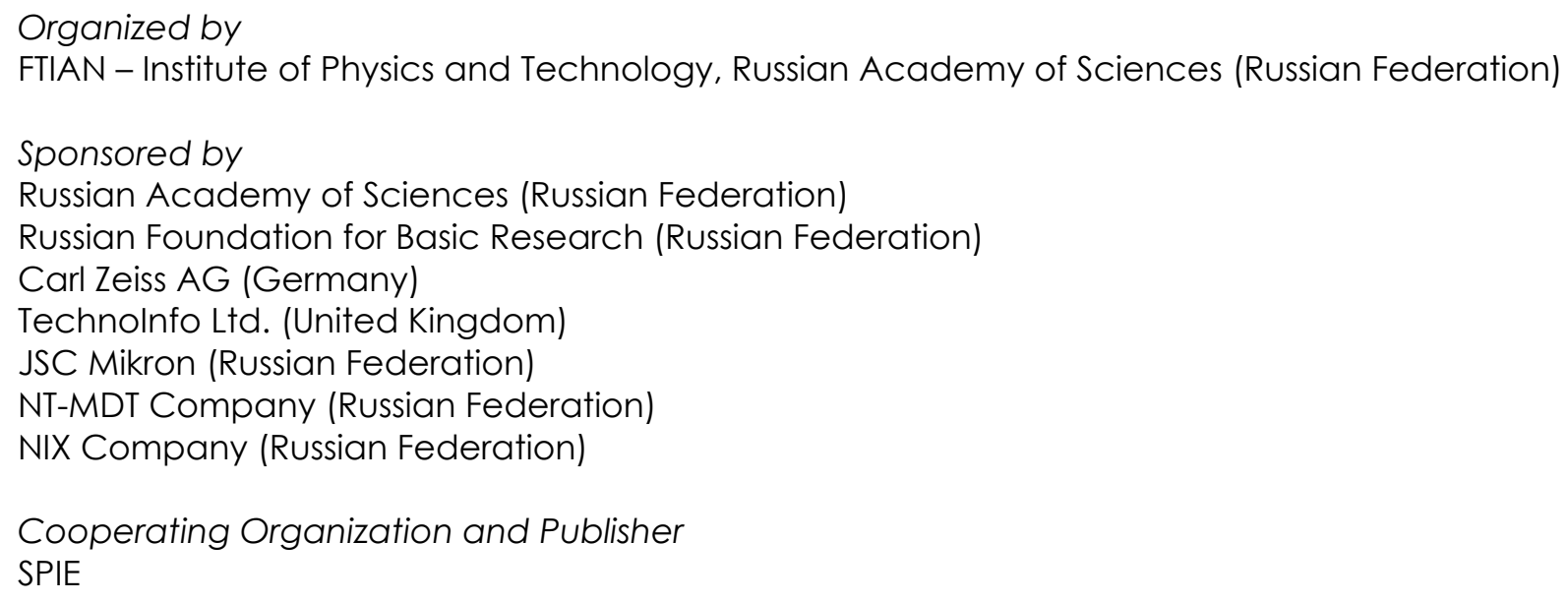

Volume 7521 
The papers included in this volume were part of the technical conference cited on the cover and title page. Papers were selected and subject to review by the editors and conference program committee. Some conference presentations may not be available for publication. The papers published in these proceedings reflect the work and thoughts of the authors and are published herein as submitted. The publisher is not responsible for the validity of the information or for any outcomes resulting from reliance thereon.

Please use the following format to cite material from this book:

Author(s), "Title of Paper," in International Conference on Micro- and Nano-Electronics 2009, edited by Kamil A. Valiev, Alexander A. Orlikovsky, Proceedings of SPIE Vol. 7521 (SPIE, Bellingham, WA, 2010) Article CID Number.

ISSN 0277-786X

ISBN 9780819479112

Published by

SPIE

P.O. Box 10, Bellingham, Washington 98227-0010 USA

Telephone +1 3606763290 (Pacific Time) · Fax +1 3606471445

SPIE.org

Copyright (C) 2010, Society of Photo-Optical Instrumentation Engineers

Copying of material in this book for internal or personal use, or for the internal or personal use of specific clients, beyond the fair use provisions granted by the U.S. Copyright Law is authorized by SPIE subject to payment of copying fees. The Transactional Reporting Service base fee for this volume is $\$ 18.00$ per article (or portion thereof), which should be paid directly to the Copyright Clearance Center (CCC), 222 Rosewood Drive, Danvers, MA 01923. Payment may also be made electronically through CCC Online at copyright.com. Other copying for republication, resale, advertising or promotion, or any form of systematic or multiple reproduction of any material in this book is prohibited except with permission in writing from the publisher. The CCC fee code is 0277-786X/10/\$18.00.

Printed in the United States of America.

Publication of record for individual papers is online in the SPIE Digital Library.

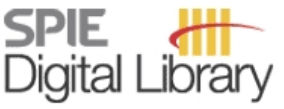

SPIEDigitalLibrary.org

Paper Numbering: Proceedings of SPIE follow an e-First publication model, with papers published first online and then in print and on CD-ROM. Papers are published as they are submitted and meet publication criteria. A unique, consistent, permanent citation identifier (CID) number is assigned to each article at the time of the first publication. Utilization of CIDs allows articles to be fully citable as soon they are published online, and connects the same identifier to all online, print, and electronic versions of the publication. SPIE uses a six-digit CID article numbering system in which:

- The first four digits correspond to the SPIE volume number.

- The last two digits indicate publication order within the volume using a Base 36 numbering system employing both numerals and letters. These two-number sets start with 00, 01, 02, 03, 04 , 05, 06, 07, 08, 09, OA, OB ... 0Z, followed by 10-1Z, 20-2Z, etc.

The CID number appears on each page of the manuscript. The complete citation is used on the first page, and an abbreviated version on subsequent pages. Numbers in the index correspond to the last two digits of the six-digit CID number. 


\title{
Contents
}

\author{
xi Conference Committee
}

$\mathrm{xV}$ Introduction

\section{SESSION 1 ADVANCED LITHOGRAPHY}

752102 Immersion lithography and double patterning in advanced microelectronics [7521-45]

T. Vandeweyer, J. Bekaert, M. Ercken, R. Gronheid, A. Miller, V. Truffert, S. Verhaegen,

J. Versluijs, V. Wiaux, P. Wong, G. Vandenberghe, M. Maenhoudt, IMEC (Belgium)

752103 Projection photolithography modeling using the finite-difference time-domain approach [7521-10]

T. M. Makhviladze, M. E. Sarychev, Institute of Physics and Technology (Russian Federation)

752104 Manufacturing of diffraction-quality optical elements for high-resolution optical systems [7521-38]

N. I. Chkhalo, A. E. Pestov, N. N. Salashchenko, M. N. Toropov, Institute for Physics of Microstructures (Russian Federation)

752105 Influence of annealing on the structural and optical properties of thin multilayer EUV filters containing $\mathrm{Zr}$, Mo, and silicides of these metals [7521-50]

N. I. Chkhalo, S. A. Gusev, M. N. Drozdov, E. B. Kluenkov, A. Ya. Lopatin, V. I. Luchin,

A. E. Pestov, N. N. Salashchenko, Institute for Physics of Microstructures (Russian Federation);

L. A. Shmaenok, PhysTeX (Netherlands); N. N. Tsybin, Institute for Physics of Microstructures

(Russian Federation)

\section{SESSION 2 PLASMA PHYSICS AND PROCESSING}

752106 The metal hard-mask approach for contact patterning [7521-46]

J.-F. de Marneffe, F. Lazzarino, D. Goossens, Th. Conard, I. Hoflijk, D. Shamiryan, H. Struyf, W. Boullart, IMEC (Belgium)

752107 Impact of plasma exposure on organic low-k materials [7521-53]

E. Smirnov, IMEC (Belgium) and Moscow Institute of Electronic Technology

(Russian Federation); A. K. Ferchichi, C. Huffman, M. R. Baklanov, IMEC (Belgium)

752108 Plasma parameters and active particles kinetics in $\mathrm{HBr}$ dc glow discharges [7521-06] A. Smirnov, Ivanovo State Univ. of Chemistry and Technology (Russian Federation) and Mikron JSC (Russian Federation); A. Efremov, V. Svettsov, Ivanovo State Univ. of Chemistry and Technology (Russian Federation); A. Islyaykin, Mikron JSC (Russian Federation)

752109 Excitation mechanism of the $\mathrm{B}^{+}$emission line at $345.1 \mathrm{~nm}$ in low-temperature plasmas [7521-02]

V.P. Kudrya, Institute of Physics and Technology (Russian Federation) 
7521 OA Application of Langmuir probe technique in depositing plasmas for monitoring of etch process robustness and for end-point detection [7521-28]

A. V. Miakonkikh, K. V. Rudenko, Institute of Physics and Technology (Russian Federation)

7521 OB Optimization of parameters of process deep plasmachemical etching of silicon for elements MEMS [7521-27]

A. I. Vinogradov, N. M. Zarjankin, J. A. Mihajlov, E. P. Prokopev, S. P. Timoshenkov, Moscow State Institute of Electronic Technologies (Russian Federation)

\section{SESSION $3 \quad$ STRUCTURES FOR PHOTONICS AND OPTOELECTRONICS}

7521 OC Defect-related luminescence from nanostructured Si layers in the 1.5-1.6 $\mu \mathrm{m}$ wavelength region [7521-19]

A. A. Shklyaev, A. B. Latyshev, Institute of Semiconductor Physics (Russian Federation) and Novosibirsk State Univ. (Russian Federation); M. Ichikawa, The Univ. of Tokyo (Japan)

7521 OD Improvement of radiation resistance of multijunction solar cells by application of Bragg reflectors [7521-25]

V. Emelyanov, N. Kaluzhniy, S. Mintairov, M. Shvarts, V. Lantratov, loffe Physico-Technical Institute (Russian Federation)

$7521 \mathrm{OE} \quad$ Laser generation in broken-gap heterostructures [7521-30]

I. Semenikhin, Institute of Physics and Technology (Russian Federation); K. A. Chao, Lund Univ. (Sweden) and Linköping Univ. (Sweden); A. Zakharova, Institute of Physics and Technology (Russian Federation)

7521 OF Noise suppression in three-level atomic system driven by quantized field [7521-33] A. Gelman, V. Mironov, Institute of Applied Physics (Russian Federation)

7521 OG Numerical methods for calculation of optical properties of layered structures [7521-56] S. A. Dyakov, Trinity College Dublin (Ireland) and Moscow Univ. (Russian Federation); V. A. Tolmachev, E. V. Astrova, loffe Physico-Technical Institute (Russian Federation);

S. G. Tikhodeev, General Physics Institute (Russian Federation); V. Yu. Timoshenko, Moscow Univ. (Russian Federation); T. S. Perova, Trinity College Dublin (Ireland)

\section{SESSION 4 THIN FILMS}

$7521 \mathrm{OH} \quad$ The thickness-dependence of the polariton effect in the single quantum well [7521-14] Yu. V. Moskalev, Yaroslavl State Pedagogical Univ. (Russian Federation); S. B. Moskovskĩ, Yaroslavl State Univ. (Russian Federation)

7521 ol Low-resistance Ge/Au/Ni/Ti/Au-based ohmic contact to n-GaAs [7521-16]

V. Kagadei, Research and Production Company Micran (Russian Federation); E. Erofeev, Scientific Research Institute of Electrical Communication Systems (Russian Federation) 
7521 0J Hf-based barrier layers for Cu-metallization [7521-39]

I. A. Khorin, Institute of Physics and Technology (Russian Federation) and Moscow State Institute of Radio-engineering, Electronics and Automation (Russian Federation);

Yu. I. Denisenko, V. N. Gusev, Yaroslavl Branch of Institute of Physics and Technology (Russian Federation); A. A. Orlikovsky, A. E. Rogozhin, Institute of Physics and Technology (Russian Federation); V. I. Rudakov, Yaroslavl Branch of Institute of Physics and Technology (Russian Federation); A. G. Vasiliev, Institute of Physics and Technology (Russian Federation) and Federal State Unitary Enterprise Pulsar (Russian Federation)

7521 OK Formation of Ge/Cu ohmic contacts to $n$-GaAs with atomic hydrogen pre-annealing step [7521-17]

E. Erofeev, Scientific Research Institute of Electrical Communication Systems

(Russian Federation); V. Kagadei, Research and Production Company Micran (Russian Federation)

$7521 \mathrm{OL} \quad \mathrm{CoSi}_{2} / \mathrm{TiO}_{2} / \mathrm{SiO}_{2} / \mathrm{Si}$ gate structure formation [7521-37]

A. E. Rogozhin, Institute of Physics and Technology (Russian Federation); I. A. Khorin, Institute of Physics and Technology (Russian Federation) and Moscow Institute of Radio-engineering, Electronics and Automation (Russian Federation); V. V. Naumov, Yaroslavl Branch of Institute of Physics and Technology (Russian Federation); A. A. Orlikovsky, Institute of Physics and Technology (Russian Federation); V. V. Ovcharov, V. I. Rudakov, Yaroslavl Branch of Institute of Physics and Technology (Russian Federation); A. G. Vasiliev, Institute of Physics and Technology (Russian Federation) and Federal State Unitary Enterprise Pulsar (Russian Federation)

\section{SESSION 5 SUPERCONDUCTING AND MAGNETIC STRUCTURES}

7521 OM Theoretical analysis of the new microwave detector based on a Josephson heterostructure [7521-40]

I. A. Devyatov, M. Yu. Kupriyanov, Lomonosov Moscow State Univ. (Russian Federation)

$7521 \mathrm{ON}$ Theoretical analysis of electronic thermal properties of the interfaces between multiband superconductors and a normal metal [7521-42]

I. A. Devyatov, M. Yu. Romashka, Lomonosov Moscow State Univ. (Russian Federation); A. V. Semenov, Moscow State Pedagogical Univ. (Russian Federation); P. A. Krutitskii, Keldysh Institute for Applied Mathematics (Russian Federation); M. Yu. Kupriyanov, Lomonosov Moscow State Univ. (Russian Federation)

752100 Superconductivity of polymers with charge injection doping [7521-44] A. N. Ionov, loffe Physico-Technical Institute (Russian Federation); R. R. Rentzsch, Freie Univ. Berlin (Germany)

7521 OP High-temperature magnetization and Mössbaver spectra of nanoparticles in a weak magnetic field [7521-36]

M. A. Chuev, Institute of Physics and Technology (Russian Federation)

$75210 Q \quad$ Mossbauer study of nanomagnetics [7521-52]

V. I. Bachurin, I. N. Zakharova, Yaroslavl State Technical Univ. (Russian Federation); M. A. Shipilin, Yaroslavl State Univ. (Russian Federation); A. M. Shipilin, Lomonosov Moscow State Univ. (Russian Federation) 
7521 OR A new antiferromagnetic nanocomposite $\mathrm{GdNiO}_{3}$ [7521-43]

A. I. Rykova, V. M. Dmitriev, E. N. Khatsko, A. V. Terekhov, A. S. Cherny, D. S. Kondrashev, B.I. Verkin Institute for Low Temperature Physics and Engineering (Ukraine); T. Mydlarz,

A. Zaleski, International Lab. of High Magnetic Fields and Low Temperatures (Poland);

A. D. Shevshenko, V. M. Uvarov, G.V. Kurdyumov Institute for Metal Physics (Ukraine)

\section{SESSION 6 PHYSICS OF NANOSTRUCTURES}

7521 OS Calculation of electrophysical parameters of thin undoped $\mathrm{GaAs}$-in- $\mathrm{Al}_{2} \mathrm{O}_{3}$ quantum nanowires and single-wall armchair carbon nanotubes [7521-18]

D. Pozdnyakov, A. Borzdov, V. Borzdov, Belarusian State Univ. (Belarus); V. Labunov, Belarusian State Univ. of Informatics and Radioelectronics (Belarus)

7521 OT Penetration of quantum-mechanical current density under semi-infinite rectangular potential barrier as the consequence of the interference of the electron waves in semiconductor 2D nanostructures [7521-29]

V. A. Petrov, A. V. Nikitin, Institute of Radioengineering and Electronics (Russian Federation)

7521 OU Calculation of the characteristics of electron transport through molecular clusters [7521-32]

Y. S. Gerasimov, Russian Research Ctr. Kurchatov Institute (Russian Federation);

V. V. Shorokhov, E. S. Soldatov, Lomonosov Moscow State Univ. (Russian Federation);

O. V. Snigirev, Russian Research Ctr. Kurchatov Institute (Russian Federation) and Lomonosov Moscow State Univ. (Russian Federation)

7521 OV Determination of electronic properties of molecular objects on the basis of nanodevices' transport characteristics [7521-48]

V. A. Malinin, V. V. Shorokhov, E. S. Soldatov, Lomonosov Moscow State Univ.

(Russian Federation)

7521 OW Electron optical spin polarization in broken-gap heterostructures [7521-24]

A. Zakharova, Institute of Physics and Technology (Russian Federation); K. A. Chao, Lund Univ. (Sweden) and Linköping Univ. (Sweden); I. Semenikhin, Institute of Physics and Technology (Russian Federation)

\section{SESSION 7 NANOSTRUCTURES FABRICATION TECHNIQUES}

7521 OX Femtosecond and nanosecond laser assistant formation of Si nanoclusters in silicon-rich nitride films [7521-07]

V. A. Volodin, Institute of Semiconductor Physics (Russian Federation) and Novosibirsk State Univ. (Russian Federation); T. T. Korchagina, G. N. Kamaev, A. Kh. Antonenko, Institute of Semiconductor Physics (Russian Federation); J. Koch, B. N. Chichkov, Laser Zentrum Hannover e.V. (Germany)

7521 OY Formation of carbonic nanostructures using PECVD and glow-discharge plasma at direct current [7521-51]

D. G. Gromov, S. A. Gavrilov, S. V. Dubkov, Moscow Institute of Electronic Technology (Russian Federation) 
7521 OZ Carbon nanostructures' catalytic growth from carbonaceous substrates in comparison with PECCVD method [7521-55]

Ye. Yu. Alekseeva, E. A. Ilichev, V. N. Inkin, D. M. Migunov, G. N. Petruhin, E. A. Poltoratskii, G. S. Rychkov, D. V. Shkodin, Federal State Research Institute of Physical Problems named after F.V. Lukin (Russian Federation)

752110 Preparation of electrodes for molecular transistor by focused ion beam [7521-31]

I. V. Sapkov, Lomonosov Moscow State Univ. (Russian Federation); V. V. Kolesov, Kotel'nikov Institute of Radioengineering and Electronics (Russian Federation); E. S. Soldatov, Lomonosov Moscow State Univ. (Russian Federation)

752111 Si wires growth by using of magnetron sputtering method [7521-34]

S. A. Evlashin, V. A. Krivchenko, P. V. Pastchenko, A. T. Rakhimov, N. V. Suetin, M. A. Timofeyev, Lomonosov Moscow State Univ. (Russian Federation)

752112 Formation of molecular transistor electrodes by electromigration [7521-47]

A. S. Stepanov, Russian Research Ctr. Kurchatov Institute (Russian Federation); E. S. Soldatov, Lomonosov Moscow State Univ. (Russian Federation); O. V. Snigirev, Russian Research Ctr. Kurchatov Institute (Russian Federation) and Lomonosov Moscow State Univ.

(Russian Federation)

752113 Formation of the atomically smooth surface of gold film and binding of gold nano-particles on it by self-assembly method [7521-54]

A. N. Kuturov, P.N. Lebedev Physical Institute (Russian Federation); E. S. Soldatov, Lomonosov Moscow State Univ. (Russian Federation); L. A. Polyakova, S. P. Gubin, Institute of General Inorganic Chemistry (Russian Federation)

752114 Investigations of nanostructured porous PbTe films with x-ray diffractometry and reflectometry [7521-22]

S. P. Zimin, V. M. Vasin, Yaroslavl State Univ. (Russian Federation); E. S. Gorlachev, Yaroslavl Branch of the Institute of Physics and Technology (Russian Federation); A. P. Petrakov, S. V. Shilov, Syktyvkar State Univ. (Russian Federation)

752115 Experimental scheme for observation of anomalous Kossel effect in semiconductor crystals [7521-35]

P. G. Medvedev, M. A. Chuev, Institute of Physics and Technology (Russian Federation);

M. V. Kovalchuk, E. M. Pashaev, I. A. Subbotin, S. N. Yakunin, Russian Research Ctr. Kurchatov Institute (Russian Federation)

752116 SEM probe defocusing method of measurement of linear sizes of nanorelief elements [7521-49]

M. N. Filippov, N.S. Kurnakov Institute of General and Inorganic Chemistry (Russian Federation); Yu. A. Novikov, A.M. Prokhorov General Physics Institute (Russian Federation): A. V. Rakov, P. A. Todua, Ctr. for Surface and Vacuum Research (Russian Federation) 
$7521 \quad 17$ Electromigration theory and its applications to integrated circuit metallization [7521-08]

T. M. Makhviladze, M. E. Sarychev, Institute of Physics and Technology (Russian Federation)

752118 Methods of cache memory optimization for multimedia applications [7521-20]

A. Kravtsov, JSC Mikron (Russian Federation)

752119 Principal problems of quality improvement for high-speed planar transmission lines issued from studies of high-Q microstrip resonators [7521-41]

A. P. Chernyaev, Lomonosov Moscow State Univ. (Russian Federation); V. A. Dravin,

P.N. Lebedev Physical Institute (Russian Federation); A. Y. Golovanov, P.N. Lebedev Physical Institute (Russian Federation) and Lomonosov Moscow State Univ. (Russian Federation);

A. L. Karuzskii, A. E. Krapivka, A. N. Lykov, V. N. Murzin, A. V. Perestoronin, A. M. Tskhovrebov, N. A. Volchkov, P.N. Lebedev Physical Institute (Russian Federation)

\section{SESSION 10 SIMULATION AND MODELING}

7521 1A Advanced atomic-scale simulation of silicon nitride CVD from dichlorosilane and ammonia [7521-09]

T. M. Makhviladze, A. Kh. Minushev, Institute of Physics and Technology (Russian Federation)

7521 1B Thermodynamic theory of interfacial adhesion between materials containing point defects [7521-11]

R. V. Goldstein, Institute for Problems in Mechanics (Russian Federation); T. M. Makhviladze,

M. E. Sarychev, Institute of Physics and Technology (Russian Federation)

7521 1C Modeling of the interfacial separation work in relation to impurity concentration in adjoining materials [7521-12]

I. M. Alekseev, T. M. Makhviladze, A. Kh. Minushev, M. E. Sarychev, Institute of Physics and Technology (Russian Federation)

7521 1D Optimization of near-surficial annealing for decreasing of depth of $p-n$-junction in semiconductor heterostructure [7521-01]

E. L. Pankratov, Nizhny Novgorod State Univ. of Architecture and Civil Engineering (Russian Federation)

7521 1E A nanoelectronic device simulation software system NANODEV: new opportunities [7521-13] I. I. Abramov, A. L. Baranoff, I. A. Goncharenko, N. V. Kolomejtseva, Y. L. Bely,

I. Y. Shcherbakova, Belarusian State Univ. of Informatics and Radioelectronics (Belarus)

7521 IF Radiation-hardening-by-design with circuit-level modeling of total ionizing dose effects in modern CMOS technologies [7521-15]

M. S. Gorbunov, Scientific-Research Institute of System Analysis (Russian Federation);

G. I. Zebrev, National Research Nuclear Univ. (Russian Federation); P. N. Osipenko,

Scientific-Research Institute of System Analysis (Russian Federation)

7521 IG Simulation results for three neutralization channel designs of a fast neutral beam source [7521-26]

A. V. Degtyarev, V. P. Kudrya, Yu. P. Maishev, Institute of Physics and Technology

(Russian Federation) 
$7521 \mathrm{1H}$ Intrinsic compact MOSFET model with correct account of positive differential conductance after saturation [7521-23]

V. O. Turin, A. V. Sedov, Orel State Technical Univ. (Russian Federation); G. I. Zebrev, National Research Nuclear Univ. (Russian Federation); B. Iñiguez, Rovira i Virgili Univ. (Spain);

M. S. Shur, Rensselaer Polytechnic Institute (United States)

Author Index 
Downloaded From: https://www.spiedigitallibrary.org/conference-proceedings-of-spie on 25 Apr 2023

Terms of Use: https://www.spiedigitallibrary.org/terms-of-use 


\title{
Conference Committees
}

\author{
Conference Chair
}

Evgeny P. Velikhov, Russian Scientific Center "Kurchatov Institute" (Russian Federation)

\author{
Conference Co-Chair
}

Kamil A. Valiev, Institute of Physics and Technology

(Russian Federation)

International Advisory Committee

A. Aseev, Institute of Semiconductor Physics, RAS, Novosibirsk (Russian Federation)

M. Baklanov, IMEC (Belgium)

V. Benine, ASML (The Netherlands)

F. Briones, Instituto de Microelectronica de Madrid, CSIC (Spain)

R. Chabicovsky, Technical University of Vienna (Austria)

M. C. Chon, Chon International Company (South Korea)

Yu. Gulyaev, Institute of Radioelectronics, RAS, Moscow (Russian Federation)

J. Gyulai, Technical University of Budapest (Hungary)

D. Esteve, Quantronics group SPEC-CEA Saclay (France)

H. L. Hwang, Taiwan

G. Karoyan, Yerevan University (Armenia)

F. Kuznetsov, Institute of Inorganic Chemistry, SB RAS, Novosibirsk (Russian Federation)

V. Labunov, Belorussian State University of Informatics and Radioelectronics (BSUIRE), Minsk (Belarus)

V. Litovchenko, Institute of Semiconductor Physics of NUAS, Kiev (Ukraine)

J. I. Nishizawa, Semiconductor Research Institute (Japan)

Yu. Pozhela, Institute of Semiconductor Physics, Vilnyus (Lithuania)

C. N. R. Rao, Jawaharlal Nehru Centre for Advanced Scientific Research (India)

H. Ryssel, Fraunhofer-Institute of Integrated Systems and Devices Technology, Erlangen (Germany)

A. Schlachetzki, Technical University of Braunschweig (Germany)

R. Suris, loffe Physico-Technical Institute, St. Petersburg (Russian Federation) 
Program Committee

K. Valiev, Chair, Institute of Physics and Technology (FTIAN), Moscow (Russian Federation)

A. Orlikovsky, Co-chair, Institute of Physics and Technology (FTIAN), Moscow (Russian Federation)

I. Neizvestnyi, Co-chair, Institute of Semiconductor Physics, SB RAS (Russian Federation)

A. Alexandrov, Lomonosov Moscow State University (Russian Federation)

V. Aristov, Institute of Microelectronics Technology, RAS, Chernogolovka (Russian Federation)

A. Berdnikov, Yaroslavl Branch of FTIAN (Russian Federation)

V. Betelin, Scientific Institute of System Researches, RAS, Moscow (Russian Federation)

Yu. Chaplygin, Moscow Institute of Electronic Technology, Zelenograd (Russian Federation)

B. Gribov, State Scientific Institute of Ultra-Pure Materials, Zelenograd (Russian Federation)

F. Komarov, Institute of Applied Physics Problems, Minsk (Belarus)

P. Kop'ev, loffe Physico-Technical Institute, St. Petersburg (Russian Federation)

Yu. Kopaev, Lebedev Institute of Physics, RAS, Moscow (Russian Federation)

V. Lukichev, Institute of Physics and Technology (FTIAN), Moscow (Russian Federation)

Yu. Ozhigov, Lomonosov Moscow State University (Russian Federation)

P. Todua, MPTI, Moscow (Russian Federation)

G. Krasnikov, JSC Mikron, Zelenograd (Russian Federation)

V. Panchenko, Institute of Laser and Informatics Technologies, RAS, Schatura (Russian Federation)

K. Salikhov, Zavoiskiy Physical-Technical Institute, RAS, Kasan (Russian Federation)

A. Sigov, Moscow State Institute of Radioengineering, Electronics and Automation (Russian Federation)

N. Salaschenko, Institute of Microstructures Physics, RAS, Nizhnii Novgorod (Russian Federation)

A. Sukhoparov, Angstrem Company, Zelenograd (Russian Federation) 
Organizing Committee

A. Orlikovsky, Chair, Institute of Physics and Technology (Russian Federation)

V. Lukichev, Co-Chair, Institute of Physics and Technology (Russian Federation)

I. Abramov, Belarusian State University of Informatics and Radioelectronics (BSUIRE) (Belarus)

Yu. Bogdanov, Institute of Physics and Technology (Russian Federation)

V. Borisenko, Belarusian State University of Informatics and Radioelectronics (BSUIRE) (Belarus)

A. Buharaev, Zavoiskiy Physical-Technical Institute (Russian Federation)

A. Berdnikov, Yaroslavl Branch of FTIAN (Russian Federation)

M. Chuev, Institute of Physics and Technology (Russian Federation)

A. Gorbazevitch, Moscow Institute of Electronic Technology (TU) (Russian Federation)

V. Gran'ko, "Integral" Company (Belarus)

B. Gurovitch, Russian Scientific Center "Kurchatov Institute" (Russian Federation)

M. Korolev, Moscow Institute of Electronic Technology (TU) (Russian Federation)

S. Nikitov, Institute of Radioelectronics (Russian Federation)

O. Pchelyakov, Institute of Semiconductor Physics, SB RAS, Novosibirsk (Russian Federation)

A. Rudy, Yaroslavl State University (Russian Federation)

V. Rubaev, NIX Company (Russian Federation)

K. Rudenko, Institute of Physics and Technology (Russian Federation)

A. Vasiliev, "Pulsar" Company (Russian Federation)

Local Committee at the Institute of Physics and Technology (FTIAN), RAS

(Russian Federation)

Prof. Vladimir Lukichev, Co-chair of Organizing Committee of ICMNE-2009

Dr. Konstantin Rudenko, Scientific Secretary of ICMNE-2009

Mr. Sergey Skalkin, Financial Director of ICMNE-2009

Dr. Vladimir Vyurkov

Dr. Igor Semenikhin

Dipl. Eng. Irina Lukianova

Dipl. Eng. Andrey Miakonkikh

Dipl. Eng. Valeriya Sosina

Dipl. Eng. Stanislav Tarasov 
Session Chairs

1 Advanced Lithography

Vladimir Lukichev, Institute of Physics and Technology

(Russian Federation)

$2 \quad$ Plasma Physics and Processing

Konstantin Rudenko, Institute of Physics and Technology

(Russian Federation)

3 Structures for Photonics and Optoelectronics

Sergey Nikitov, Institute of Radioelectronics (Russian Federation)

$4 \quad$ Thin Films

Denis Shamiryan, IMEC (Belgium)

$5 \quad$ Superconducting and Magnetic Structures

Mikhail Kupriyanov, Lomonosov Moscow State University

(Russian Federation)

$6 \quad$ Physics of Nanostructures

Vladimir Vyurkov, Institute of Physics and Technology

(Russian Federation)

$7 \quad$ Nanostructures Fabrication Techniques

Anatoly Vyatkin, Institute of Microelectronics Technology

(Russian Federation)

8 Micro- and Nanostructures Characterization

Eduard Rau, Lomonosov Moscow State University (Russian Federation)

9 Devices and ICs

Boris Konoplev, Southern Federal University (Russian Federation)

10 Simulation and Modeling

Igor Abramov, Belarusian State University of Informatics and Radioelectronics (BSUIRE) (Belarus) 


\section{Introduction}

This volume contains selected papers from those presented at the International Conference on Micro- and Nanoelectronics 2009 (ICMNE-2009) which was held in Zvenigirod, Russia, October 5-9, 2009. The conference is a biannual event and continues the series of conferences focusing on current physical and technological problems in microelectronics and promising nanosized devices. Since 1992, the Institute of Physics and Technology of the Russian Academy of Sciences (FTIAN) has been the permanent organizer of the ICMNE conferences, and since 2003, the ICMNE has been an SPIE-affiliated conference.

The goals of the 2009 conference were to look forward to new concepts and technologies of integrated devices, and to join efforts of scientists in answer to the challenges of industry scaling down ICs to nanometer design rules. ICMNE 2009 featured a wide scope of presented papers in the urgent fields of the physics of micro- and nanostructures, techniques for its characterization, and bottleneck points in the technologies of micro- and nanoscale devices. The Conference focused on topical problems that were highlighted in the following sessions:

- Advanced Lithography

- Plasma Physics and Processing

- Structures for Photonics and Optoelectronics

- Thin Films

- Superconducting and Magnetic Structures

- Physics of Nanostructures

- Nanostructures Fabrication Techniques

- Micro- and Nanostructures Characterization

- Devices and ICS

- Simulation and Modeling

The scientific program comprised of a collection of invited and contributed papers from scientists employed at European and Siberian Regions of Russia, Eastern and Western Europe, and Asia. The invited lectures on current achievements and challenges in microelectronic and superconducting devices were delivered by scientists from USA, France, Belgium, Germany, Sweden, Japan, and Russia. The contributed presentations were made by speakers from academic institutions, universities, and industry. More than 80 contributions were discussed at oral sessions; the others were presented as posters.

Most of the papers at ICMNE are the results of latest investigations. We hope that helpful discussion of these works at the sessions of the conference and during personal contacts between attendees will promote the research activity in the 
microelectronics community. Additional information about ICMNE can be found at the conference website http://www.icmne.ftian.ru/

Konstantin Rudenko

Dr. of Sci., Scientific Secretary of ICMNE 2009 